\title{
MARTIN UHÁL' \\ Słowacja i lata wolności Kościoła słowackiego w perspektywie Roku Wiary
}

Kościół zakończył przeżywanie roku, którego celem było m.in. ożywienie wiary. Dla Słowaków, z wielu powodów, było to ważne wydarzenie. Najpierw dlatego, że emerytowany już papież Benedykt XVI ogłosił go jako wiążący dla całego Kościoła, chcąc w ten sposób uczcić pięćdziesiątą rocznicę II. Soboru Watykańskiego oraz dwudziestą rocznicę wydania Katechizmu Kościoła katolickiego $^{1}$. Ponadto dla Kościoła na Słowacji Rok Wiary zbiegł się z obchodzoną tutaj 1150 rocznicą przybycia Cyryla i Metodego na ziemię słowacką. Konferencja Episkopatu Słowacji ogłosiła rok św. św. Cyryla i Metodego jako część Roku Wiary, bo to właśnie oni byli zwiastunami Ewangelii dla dzisiejszych Słowaków. Wydarzenia te są szczególna okazją, aby przyjrzeć się stanowi wiary na Słowacji i jej rozwojowi w ostatnim dwudziestoleciu, kiedy to Kościół cieszył się wolnością oraz ocenić, na ile wykorzystał ten czas jako okazję jej pogłębienia.

Sytuację na Słowacji w ostatnich dwudziestu kilku latach wyznacza pewna liczba zjawisk, które wpłynęły zarówno na życie Kościoła, jak i całego społeczeństwa. Ostatecznie odegrały one znaczącą rolę w określeniu miejsca Kościoła we współczesnym, sekularyzowanym społeczeństwie słowackim, a także wpłynęły na jego zdolność do zachowywania i rozwijania wiary jako wartości życia społecznego oraz ściśle religijnego.

Martin U H Á L', ks. doc. ThDr, Teologická fakulta Košice, Katolícka univerzita Ružomberok, e-mail: uhal@ku.sk

\footnotetext{
${ }^{1}$ Por. http://www.tkkbs.sk/view.php?cisloclanku=20120105025 [odczyt: 15.05.2013].
} 


\section{Zjawiska w życiu społecznym}

$\mathrm{Na}$ stan wiary Słowaków duży wpływ miały wydarzenia społecznopolityczne, które na tyle silnie oddziaływały, że zaciążyły również na postawie wierzących i ich praktykach religijnych.

Jednym ze znaków politycznego przełomu było poszukiwanie przez nową władzę oparcia w środowisku kościelnym i w jego strukturach. Od samego początku rządzące partie polityczne, dla osiągniecia własnych celów, traktowały Kościół instrumentalnie. Chodziło o pokazanie własnej działalności jako zgodnej z chrześcijańskimi tradycjami i zwyczajami, albo przeciwnie - odrzucając wszystko to, co chrześcijańskie, aby podkreślić swoją całkowitą niezależność i jakikolwiek związek z Kościołem. Stosunek zatem wobec Kościoła stał się swoistym kryterium określającym charakter poszczególnych partii politycznych.

Zmieniano także i tworzono nowe prawa, które miały na celu umożliwienie legalnej prywatyzacji w sposób niestandardowy. Prywatyzacja była uwikłana w polityczne rozgrywki i stanowiła narzędzie budowania partyjnych układów.

Pojawił się problem rosnącej sekularyzacji. Ludzie nie potrafili sobie wyobrazić, jak można być równocześnie człowiekiem wierzącym i zarazem dobrym obywatelem. Jakby te dwa wymiary ze sobą się kłóciły. Pod silnym wpływem mediów rośnie w społeczeństwie przekonanie, że jeśli polityka i Kościół nie zostaną od siebie całkowicie oddzielone, to pojawi się nowy totalitaryzm, tzw. czarny totalitaryzm. Towarzyszy temu równocześnie zarzut, że Kościół ingeruje w życie polityczne.

$\mathrm{Na}$ to wszystko nakłada się kryzys ekonomiczny słowackich rodzin. Utrata pracy niosła ze sobą utratę zabezpieczenia materialnego i poczucie niepewnej przyszłości. Powszechnie wzrosły ceny, szczególnie w służbie zdrowia. Zaczyna się emigracja w poszukiwaniu pracy. Pustoszeją niektóre obszary przygraniczne, co pociąga za sobą zmiany w posłudze pastoralnej Kościoła oraz konieczność stworzenia nowego modelu duszpasterstwa dla tych, którzy emigrując do nowych miejsc, pozbawieni są opieki pasterskiej.

Znaczący wypływ na sytuację społeczną miało przystąpienie Słowacji w 2004 r. do Unii Europejskiej. Wiązało się to ze sporym wysiłkiem zmierzającym do przezwyciężenia negatywnych pozostałości po korupcyjnym okresie rządów, zwanym „meciaryzmem” oraz próbą spełnienia kryteriów umożliwiających przystąpienie do Unii Europejskiej². Wiązało się to z konie-

2 Chodzi o rządy V la di mír a M e č i a r a, tymczasowego prezydenta Słowacji w latach 1993 i 1998, a także premiera w latach 1992-1994 i 1994-1998, który korzystał z władzy, aby załatwiać własne interesy i swoich sympatyków. Przeprowadzona przez niego prywatyzacja odbiła się fatalnie na słowackiej gospodarce. 
cznością wprowadzeniem licznych zmian w życiu społecznym i administracyjnym, m.in. zmianę prawa, która niekiedy szła dalej niż wymagało to prawodawstwo Unii Europejskiej.

Słowacja zaczęła również odczuwać skutki globalizacji, choć w mniejszym stopniu niż to miało miejsce w innych krajach. Kościół jednak do dzisiaj nie znalazł odpowiedzi na procesy związane ze zjawiskiem globalizacji, zarówno $\mathrm{w}$ społeczeństwie słowackim jak i wewnątrz wspólnoty wierzących. Z wyjątkiem katechizacji, brakuje mu wyraźnej koordynacji podstawowych działań pastoralnych. Natomiast zbytnia koncentracja na restytucji majątku kościelnego, budowie kościołów i renowacji zabytków rodzi niepotrzebne konflikty i osłabia skuteczność podstawowej działalności duszpasterskiej.

Wreszcie wspomnieć trzeba stale pogłębiający się konsumpcjonizm. Pojawia się nowa warstwa społeczna, silna politycznie i gospodarczo, którą tworzą osoby zamożne, mające coraz większy wpływ na życie społeczne. Poszerzanie się tego zjawiska oraz pragnienie podążania za tym trendem powoduje, że coraz większa liczba ludzi koncentruje się na karierze i sukcesie, pozostawiając życie religijne na uboczu i traktując wiarę jako swego rodzaju folklor. Ostatecznie prowadzi to do osłabienia lub zaniku praktyk religijnych.

\section{II. Środowisko kościelne i jego osiągnięcia}

W przedstawionej wyżej sytuacji społeczno-politycznej Słowacji, Kościół podejmował liczne inicjatywy, zmierzające do odnalezienia właściwego sobie miejsca $\mathrm{w}$ nowej rzeczywistości, jaka nastała po upadku komunizmu. Nie brakowało pośród nich tych, które stanowią nową jakość w działalności słowackich środowisk kościelnych. Spróbujmy najpierw wymienić te osiągnięcia, które miały wpływ na życie Kościoła i w jakiś sposób wpłynęły również na życie duchowe i rozwój wiary lub działalność duszpasterską.

W sferze materialno-organizacyjnej wspomnieć trzeba zwrot skonfiskowanego przez państwo mienia kościelnego. Uporządkowano formy działania i administracji, powołano $\mathrm{w}$ parafiach rady ekonomiczne i duszpasterskie, które dzisiaj wyznaczają swoisty standard funkcjonowania parafii.

Zbudowano w tym okresie wiele nowych kościołów. Tylko w archidiecezji koszyckiej, która obejmuje 210 parafii, zostało wybudowanych 150 kościołów i ustanowiono ok. 75 nowych parafii. Pojawiły się również kościoły filialne, których dotąd nie było $\mathrm{w}$ archidiecezji.

Ożywia się kościelna prasa. Zaczęły się ukazywać odnowione czasopisma i pojawiły się nowe tygodniki o treści religijnej. Powstało katolickie radio „Lumen” i telewizja „Lux”. 
Rozwinęły się też specjalistyczne formy duszpasterstwa, np. duszpasterstwo wojskowe, policji, studentów. Powstały diecezjalne centra młodzieżowe, prowadzi się duszpasterstwo w szpitalach, więzieniach, a także powołano duszpasterstwo społeczności romskiej. Dokonano odnowy nauczania religii, które prowadzone jest we wszystkich szkołach w ramach zwykłego planu lekcji. Dokonała się odnowa zakonów i ich działalności oraz rozwój nowych form zakonnej aktywności, np. salezjanie prowadzą duszpasterstwo wśród społeczności romskiej. Pojawiły się także nowe ruchy, które wcześniej działały w ukryciu, np. Focolare, Światło-Życie, katolickie harcerstwo i inne.

Poza wyraźnymi oznakami ożywienia struktur działalności kościelnej pojawiały się również inne zmiany lub wydarzenia, które miały wpływ na życie duchowe oraz rozwój wiary w społeczności słowackiej. Do takich należy zaliczyć wizyty papieskie. W czasie ostatnich dwudziestu czterech lat życia Kościoła w wolności papież Jan Paweł II odwiedził Słowację trzykrotnie. Pierwszy wizyta odbyła się w dniach 21-22 kwietnia 1990 r. Papież odwiedził wówczas Czechosłowację. Po uroczystej liturgii w Pradze i w Velehradzie, Jan Paweł II odwiedził Bratysławę, gdzie na lotnisku w Vajnorach celebrował mszę świętą ${ }^{3}$.

Kolejna wizyta odbyła się w 1995 r. Papież w piątek, 30 czerwca odwiedził Bratysławę i Nitrę. W sobotę, 1 czerwca: był w Šaštíne i Bratysławie. W niedzielę, 2 czerwca odwiedził Košice, Prešov. W poniedziałek, 3 czerwca udał się do Levočy, a następnie w Tatry. Podczas tej wizyty papież kanonizował koszyckich męczenników.

Trzecia wizyta odbyła się w dniach 11-14 września 2003 r. Jan Paweł II odwiedził diecezję bańskobystrzycką, rożnawską i archidiecezję bratysławskotrnawską, gdzie w podczas mszy świętej kanonizował błogosławionego Vasila Hopka, greckokatolickiego biskupa pomocniczego w Preszowie ${ }^{4}$.

Każda z tych wizyt była manifestacją wiary i wyrazem troski o Kościół oraz jego jedność. Przynosiła wzmocnienie wiary oraz pogłębienie zainteresowania Kościołem i jego życiem. Znajdowało to odbicie w treści listów pasterskich i odezwach biskupów, które miały przygotować wierzących na przybycie papieża.

3 Por. http://www.kbs.sk/obsah/sekcia/h/konferencia-biskupov-slovenska/p/historicky-prierez [odczyt: 15.05.2013].

${ }_{4}$ Por. http://www.vatican.va/news_services/liturgy/2003/documents/ns_lit_doc_20030911_ slovacchia_sk.html; por. http://www.bbc.co.uk/slovak/news/story/ 2005/04/050402_embpope _slovakia.shtml [odczyt: 15.05.2013]. 
Odrębnym zagadnieniem jest sprawa tzw. dziesięciolecia odnowy, która związana była z okresem lat dziewięćdziesiątych ${ }^{5}$. W każdym roku podczas całej dekady wyznaczano główny temat lub hasło, wokół którego miała się koncentrować praca katechetyczna i duszpasterska. Dominowały takie tematy jak: Bóg Ojciec, Jezus Chrystus, Duch Święty, Kościół, ale również małżeństwo, rodzina $\mathrm{i}$ inne.

Całość pracy tego okresu nie doczekała się odpowiedniej oceny. Realizacja programów duszpasterskich w parafiach i diecezjach miała swoje słabe strony. Zazwyczaj tematy lub materiały pomocnicze docierały z opóźnieniem, często już nieaktualne. Niektóre istniały tylko formalnie. To, co zrealizowano w najodpowiedzialniejszy sposób, to kazania tematyczne w czasie mszy niedzielnych. Każdy rok miał określony temat, który był myślą przewodnią homilii, kazań i pracy duszpasterskiej. Poza tematycznymi kazaniami i sporadycznymi przedsięwzięciami $\mathrm{w}$ większości parafii te wszystkie założenia pozostawały niezrealizowane.

Wspomnianemu dziesięcioleciu odnowy brakowało autorefleksji, tak by Kościół mógł ocenić, jaki wpływ na społeczeństwo miała jego praca, co było pomocne $\mathrm{w}$ działalności poszczególnych duszpasterzy, co miało największe znaczenie dla świeckich wiernych. Zabrakło informacji zwrotnej, którą mogłoby przekazać społeczeństwo.

Kolejna inicjatywa, o której należy wspomnieć, to próba stworzenia po roku 2000 programu ewangelizacyjnego i duszpasterskiego. Chodziło o wypracowanie jednolitej koncepcji ewangelizacji, a przede wszystkim duszpasterskiej pracy Kościoła. Opracowano program duszpasterski Kościoła katolickiego. Istniał jednak formalnie, ponieważ nie miał charakteru obowiązującego w całym kościele lokalnym. Pozostał więc prawie zupełnie niezauważony. Ten program duszpasterski przewidziano na lata 2000-2006. Po nim był następny, opracowany na lata 2007-2013 i obejmował już nie wszystkie obszary pracy duszpasterskiej, ale tylko wybrane zagadnienia oraz określone grupy społeczne. Historia jego realizacji przypomina jednak dzieje poprzedniego. Aktualnie dobiega końca czas przewidziany na realizację tego drugiego programu, ale brakuje sygnałów, aby konsekwentnie wprowadzano go w życie. Może za wyjątkiem Komisji ds. Problemów Socjalnych przy Konferencji Episkopatu Słowacji, która próbowała w jakikolwiek sposób realizować jego założenia, głównie dlatego, że jest w niej spora liczba świeckich wiernych, odpowiedzialnie podchodzących do swej pracy. W marcu 2013 r. zebrała się wspomniana komisja, aby ocenić swoją dotychczasową działalność, przede wszystkim przy tworzeniu klubów socjalnych

$5 \mathrm{Na}$ dziesięciolecie odnowy wskazał również J a n P a w e $\nmid$ I I w czasie pierwszej wizyty w 1990 r. - por. http://www.kbs.sk/obsah/sekcia/h/dokumenty-a-vyhlasenia/p/dokumentypapezov/c/ navsteva-svateho-otca-v-csfr [odczyt: 15.05.2013]. 
w parafiach oraz próbie połączenia różnorodnych przedsięwzięć na gruncie diecezjalnym, w określonych obszarach i grupach społecznych. Poza tą inicjatywą kolejny raz nie ma pełniejszej oceny wspomnianego programu duszpasterskiego.

Nie sposób pominąć synodów diecezjalnych, które miały pracować nad nowymi wyzwaniami i potrzebami pojawiającymi się $\mathrm{w}$ duszpasterstwie. $\mathrm{Z}$ dostępnych na Słowacji źródeł wynika, że do tej pory miały miejsce trzy synody: w Koszycach ${ }^{6}$, Bańskej Bystrici ${ }^{7}$ i w diecezji spišskej ${ }^{8}$. Chociaż nie obejmowały one całej Słowacji, były przede wszystkim próbą znalezienia nowego modelu działalności duszpasterskiej i nowej formy układania relacji i współpracy w parafiach. Główny nacisk kładziono na relacje między duchownymi i współpracownikami świeckimi. Ich potencjał do dziś nie jest dostatecznie doceniony i wykorzystany. Oprócz tego ważnym pytaniem była kwestia samofinansowania i zarządzania majątkiem parafialnym.

$\mathrm{Na}$ koniec wspomnieć trzeba rozwój teologii i nauk teologicznych. Zaraz po przemianach społecznych zaczęły powstawać nowe seminaria i wydziały teologiczne. Obecnie istnieją na Słowacji trzy wydziały teologii katolickiej. Należą do nich również cztery instytuty zamiejscowe. Wydziały znajdują się na Uniwersytecie Komeńskiego, na Katolickim Uniwersytecie w Rużomberku oraz na Uniwersytecie Preszowskim.

Po upadku komunizmu wielu księży, ale również i świeckich zaczęło studiować teologię. Diecezje musiały zatroszczyć się o potrzebną do ich sprawnego funkcjonowania kadrę pracowników sądów, kurii i seminariów. Bardzo znaczącą pomoc w tym względzie okazały polskie uczelnie, zwłaszcza Papieska Akademia Teologiczna w Krakowie i Katolicki Uniwersytet Lubelski. Zwiększenie się liczby teologów ożywiło środowisko teologiczne i wymianę poglądów, pomnożyło możliwości spotkań naukowych i konferencji rozwijających dialog między specjalistami oraz rozwój dyscyplin teologicznych. Zaistniała też szeroka możliwość odbywania studiów poza granicami Słowacji.

6 Dekret zwołujący synod został ogłoszony w święto św. Andrzeja, 30 listopada 2002 r. - por. http://synoda.rimkat.sk/dekret.php [odczyt: 15.05.2013].

Synod diecezjalny otworzył Jan Paweł II w czasie swej drugiej wizyty, dnia 12 września 2003 - por. http://www.sme.sk/c/1095996/papez-otvoril-banskobystricku-dieceznusyno du.html; por. http://www.katolickenoviny.sk/22-2002-diecezna-synoda-banska-bystrica/ [odczyt: 15.05.2013]

8 Dekret o jego otwarciu został odczytany w niedzielę, 21 maja 2006 r. - por. http://dieceza.kapitula.sk/userfiles/file/Dokumenty\%202DS_komplet.pdf [odczyt: 15.05.2013]. 


\section{Pasywa kościelnej działalności}

Omawiając sytuację Kościoła na Słowacji należy uczciwie przyznać, że istnieją obszary, które w ostatnich latach miały raczej negatywny wpływ na rozwój wiary i przyczyniły się do wzrostu sekularyzacji i kryzysu wiary.

Przede wszystkim należy zwrócić uwagę na nasilający się proces zmian i ich intensyfikację w społeczeństwie. W ciągu ostatnich dwudziestu lat poziom wiary zwolna zbliża się do standardu sekularyzowanej Europy. Można dostrzec, że niektóre zasady moralne i etyczne trwale przeniknęły w życie społeczeństwa. Mniej się kradnie (chodzi przede wszystkim o środowisko robotnicze, w polityce zaś sytuacja zdaje się wyglądać inaczej). Mniej się kłamie - przynajmniej w mediach i codziennej komunikacji międzyludzkiej, możliwe, że nieznacznie też wśród polityków. Ludzie są bardziej pewni siebie i odpowiedzialni. Widoczna jest gotowość do bezinteresownej pracy na rzecz społeczeństwa $\mathrm{w}$ ramach aktywnej postawy obywatelskiej. Zwiększa się świadomość polityczna i świadomość własnych praw. Mimo tego, wzrost zwykłej kultury społecznej jest raczej mierny.

W Kościele słowackim zmiany te przebiegają jeszcze wolniej. Zjawisko to jest widoczne w każdym obszarze na styku Kościoła $z$ życiem i rozwojem społecznym. Nie jest to związane z modelem pracy duszpasterskiej (może za wyjątkiem katechezy), ale raczej $\mathrm{z}$ wymianą generacji $\mathrm{w}$ szeregach hierarchii kościelnej.

Ubywa wierzących i zauważa się wśród nich wyraźny brak średniego pokolenia $^{9}$. Ubywa też stopniowo młodzieży, ponieważ wzrasta ona w środowisku, które nie sprzyja życiu w bliskości z Kościołem. W ramach duszpasterstwa i życia parafialnego nie wprowadzono prawie żadnych zmian. Seminaria duchowne ciągle jeszcze koncentrują się na formacji wokół liturgii (bo jest centrum życia Kościoła i zapowiedzią liturgii niebiańskiej). Brakuje duszpasterstwa stanowego i rodzinnego. Katecheza szkolna jest niewystarczająca. Liczne przedsięwzięcia są sklerykalizowane, świeccy pozostając poza liturgią i katechezą szkolną, mają mały przystęp do zadań w ramach życia parafialnego, którymi mogliby się zająć w miejsce duchownych przeciążonych, często pracą.

Duchowni, jak i przyszli prezbiterzy, nie są przygotowywani do zarządzania. Nie zdobywają umiejętności pracy $\mathrm{w}$ zespole $\mathrm{i}$ podstaw wiedzy $\mathrm{z}$ zakresu

${ }^{9}$ O M e c i a r z e i jego partii, której inteligencja lub zorientowana politycznie część Słowacji nie mogła się pozbyć, również mówiło się, że zmiana nastąpi dopiero wtedy, gdy wymrze jego elektorat. Tak też się stało. To samo czeka i Kościół - zmiana nastąpi, gdy odejdą osoby obecne w jego strukturach zarządczych. 
zarządzania, tak by móc na przykład kierować organizacjami non profit. Księża są zbyt przeciążeni obowiązkami i z twego powodu bardzo szybko podlegają wypaleniu.

Brakuje formacji ciągłej kapłanów. Po święceniach nikt już nie dba o dalszą formację kapłanów oraz o rekolekcje lub dni skupienia czy comiesięczne spotkania kapłanów w dekanacie. Jeśli są organizowane, to niestety traktowane są bardzo formalne. Program jest ustalany centralnie i nie odpowiada potrzebom i oczekiwaniom.

Nie weryfikuje się pewnych stereotypów czy założeń. Na przykład cały czas twierdzi się, że Słowacja jest krajem katolickim. W badaniach socjologicznych wiele osób deklaruje się jako wierzący. Nie ma to jednak żadnego związku z realną sytuacją Kościoła i Jego wpływu na społeczeństwo. Społeczność ochrzczonych żyje bardzo często w taki sposób, ,jakby Boga nie było“. To dość wyraźnie dezorientuje biskupów, którzy ciągle są przeświadczeni, że Kościół ma oparcie we wszystkich warstwach społecznych.

Kościół pozostaje zamknięty we własnym świecie. Biskupi żyją w przekonaniu, że wspólnota kościelna ma swój wewnętrzny świat, do którego społeczeństwo nie powinno się mieszać. Nie uświadamiają sobie, że w sekularyzowanej społeczności Kościół jest postrzegany jako jednostka społeczna. Dlatego wymaga się od niego transparentności, otwartości, przystępności, jawnego składania informacji i chęci współpracy. Biskupi przyjmują często bezkrytyczną postawę wobec aktualnych problemów, nie przewidując, jak na to zareaguje opinia publiczna. Tymczasem niewyjaśnione wydarzenia i sytuacje wywołują zakłopotanie i zdziwienie, co pogłębia napięcia i nie ułatwia procesu ewangelizacji, a także kształtuje negatywny obraz Kościoła.

Wspomnieć również należy, że Kościół nie potrafi pokazywać własnych zasług i osiągnięć na forum publicznym. Były propozycje, żeby organizować regularne konferencje prasowe, na których informowałby media $o$ przygotowywanych inicjatywach oraz przedstawiałby swój pogląd na nurtujące społeczeństwo problemy. Nie znalazło to jednak zrozumienia ${ }^{10}$.

\section{Sprawa arcybiskupa Bezáka}

Ta sytuacja powinna należeć do odosobnionych, ale, niestety, nabrała dość znaczącego rozmiaru, stąd można ją dziś zaliczyć do kościelnych problemów. Wywołała wiele emocji i różne reakcje, zarówno po stronie kościelnej jak i społecznej.

10 Jeżeli papież każdej niedzieli podczas modlitwy Anioł Pański ma coś do powiedzenia, $\mathrm{z}$ całą pewnością i my znaleźlibyśmy tematy do rozmów, by pokazać Kościół w pozytywnym świetle. 
2 lipca 2012 r., po trzech latach urzędowania, odwołano arcybiskupa archidiecezji trnawskiej ${ }^{11}$. Przeszedł na emeryturę $\mathrm{i}$ usunął się $\mathrm{z}$ przestrzeni publicznej. Ta sytuacja podzieliła społeczeństwo słowackie, a skutki są odczuwane do tej pory. Wpłynęło na to wiele czynników.

Najpierw, ze względu na powolne tempo niektórych przemian, dokonujących się wewnątrz wspólnoty kościelnej. Kościół zdaje się niekiedy nie nadążać za dojrzewaniem społeczeństwa, które wykazuje większą elastyczność niż środowisko kościelne.

Innym powodem był wybór na arcybiskupa człowieka o charakterystycznych cechach, związanych z jego formacją zakonną. Był jedynym biskupem w słowackim episkopacie, pochodzącym ze zgromadzenia zakonnego. To zawsze rodzi pewne różnice $\mathrm{i}$ inne podejście do wielu spraw w stosunku do pozostałych biskupów, którzy pracowali wcześniej samodzielnie w parafiach, bez wspólnoty braci, bez żadnych kontaktów $\mathrm{z}$ zagranicą, co $\mathrm{w}$ zakonach było możliwe zwłaszcza w ostatnich dwudziestu latach. W życiu zakonnych ma się styczność z innego typu obowiązkami i zwyczajami, ma się inne podejście do majątku, który przecież jest wspólny. Widać to choćby teraz na przykładzie nowego papieża Franciszka, który po długim czasie jest pierwszym zakonnikiem na Stolicy Piotrowej.

Nie bez znaczenia było dążenie do zbyt szybkiego wprowadzania zmian. Arcybiskup podjął wiele pozytywnych innowacji w swojej diecezji i w poszczególnych jej parafiach, ale było to realizowane zbyt pochopnie. W pierwszym roku swojego urzędowania odwołał wszystkich dziekanów w diecezji i zastąpił ich nowymi, wybranymi również spoza diecezji. W wielu innych kwestiach działał zbyt indywidualnie, nie biorąc pod uwagę poglądów pozostałych biskupów, zwłaszcza w kwestiach, które powinny mieć jednolite $\mathrm{i}$ wspólne rozwiązania dla całej Słowacji, mi.in. postawa wobec problemów społecznych, wydawanie listów pasterskich itp.

Między biskupami brakowało jedności nawet tam, gdzie wymagała tego sytuacja, co pogłębiało istniejące już podziały. Do tego dochodziły inne podziały, o trochę mniejszym znaczeniu, o których nieoficjalnie mówiło się w Kościele i na forum społecznym. Wszystko to wpłynęło na odwołanie arcybiskupa z jego urzędu. Brak jednak podania do publicznej wiadomości powodów jego odwołania, pogorszył tylko jeszcze bardziej rozłam w Kościele lokalnym.

Nawet bez znajomości oficjalnych powodów, było jasne, że sytuacja odwołania arcybiskupa i następujące po niej zarzuty o nadużycia majątkowe i

\footnotetext{
${ }^{11}$ Nominację biskupią otrzymał 18 kwietnia 2009 r. - por. http://www.tkkbs.sk/view. php?

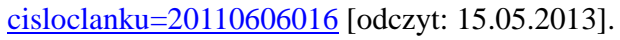


inne sprawy, spowodowały, że episkopat wyraźnie podzielił się na dwie grupy. Arcybiskup zbyt ostro odrzucił pewne wspólne inicjatywy. Nie pozwalał odczytywać listów pasterskich przeznaczonych dla całej Słowacji. Nie brał też udziału we wspólnych przedsięwzięciach czy działaniach. Publicznie krytykował współbraci biskupów za ich staroświeckie podejście. To, że brak jedności wśród biskupów był rzeczywiście jedną $\mathrm{z}$ głównych przyczyn odwołania go, potwierdził list papieża Benedykta XVI, w którym na prośbę Konferencji Episkopatu Słowacji wyjaśnił powodu swojej decyzj1 ${ }^{12}$.

Prawdą jest, że już od początku powołania Konferencji Episkopatu nie było jedności między biskupami w wielu sprawach. Czy to chodziło o powstanie oddzielnej Słowackiej Republiki, czy o postawę wobec Meciara, lewicy i innych problemów. Ale mimo tego biskupi zawsze $\mathrm{w}$ kwestiach nauki wiary występowali wspólnie i jednomyślnie. Tymczasem abp Robert Bezák od początku chciał przeorganizować prawie wszystko, przedstawiając dotychczasową pracę swego poprzednika w negatywnym świetle i popadając $\mathrm{w}$ pewien konflikt z pozostałymi biskupami.

W tym miejscu konieczne jest pewne dopowiedzenie. Dotychczas Kościół słowacki w licznych sprawach postępował ,po swojemu“, ponieważ nie miał w tym względzie żadnego doświadczenia. Do tej pory, poza obiektami sakralnymi i parafiami, nie miał majątku, którym musiałby zarządzać, wynajmować go, sprzedawać itp. Zazwyczaj musiał ukrywać swoją działalność przed państwem, bo podlegała ona urzędowym restrykcjom. Nie można zatem się dziwić, że księża ukształtowani $w$ takiej atmosferze, działali zgodnie ze swoim doświadczeniem. Nie mieli nigdy żadnego przygotowania z zakresu zarządzania ludźmi czy majątkiem. Dlatego też ci, którzy aktualnie wstępują do stanu duchownego muszą $\mathrm{z}$ delikatnością podchodzić do sposobu pracy starszego pokolenia, mając świadomość, że dołączają do wspólnoty, w której zastępują starszych braci oraz biorą odpowiedzialność za budowanie jedności Kościoła

Trzeba też wyraźnie podkreślić, że w czasie rozwiązywania sprawy abpa Bezáka miało miejsce wiele uchybień po obu stronach. Podczas urzędowych wizytacji zadawano prowokacyjne pytania. Nie brano także pod uwagę głosu opinii publicznej. Wychodziło się z założenia, że skoro sprawa dotyczy Kościoła, to ludzie niezwiązani z nim nie powinni się do tego mieszać, zapominając, że sprawa nabrała publicznego charakteru, wywołując wiele emocji i trwających do

12 Starannie i obiektywnie zapoznatem się z ta poważna i niepokojąca sytuacja i po dtugiej modlitwie, majac obowiazek wypływajacy z miłości, muszę odnowić kolegialność między wami oraz uporządkować sposób pasterzowania w archidiecezji trnawskiej wedlug autentycznego ducha II Soboru Watykańskiego, którego pięćdziesiata rocznicę właśnie przeżywamy - por. http://www.tkkbs.sk/view.php?cisloclanku=20121108025; por. http://www.hlavnespravy.sk/ benedikt-xvi-napisal-list-biskupom-ohladne-bezaka/45835/ [odczyt: 15.05.2013]. 
dzisiaj podziałów. Szczęśliwym zbiegiem okoliczności, wybór nowego papieża trochę uspokoił sytuację i skierował uwagę wierzących na inne problemy. Niezbyt fortunnym było także upublicznienie przez arcybiskupa informacji o swoim odwołaniu i przyjęcie zaproszenie do wystąpienia w mass mediach, nie biorąc pod uwagę skutków (podział Kościoła), których przecież musiał być świadomy. To rodzi pytanie, czy działał w myśl zasady: Sentire cum Ecclesia ${ }^{13}$.

Analizując wszystkie zebrane $\mathrm{w}$ tej sprawie fakty można powiedzieć, że liczne inicjatywy i środki, które podjął arcybiskup były dobre i potrzebne. Kościół musi się otworzyć i prowadzić dialog ze światem. Przecież ci, którzy na nas spoglądają muszą widzieć nasze czyny, żeby mogli chwalić naszego Ojca w niebie (por. 1P 2,12). Dotyczy to również spraw związanych z zarządzaniem majątkiem i finansami. Nie jest to wprawdzie zarządzanie majątkiem publicznym i nie podlega prawu państwowemu, ale sposób w jaki się do tego podchodzi jest częścią apostolatu Kościoła. Będzie to jasny komunikat o otwartości, przejrzystości i uczciwości Kościoła, co we współczesnej erze demokracji nabiera coraz większego znaczenia. Wspomnieć też trzeba konieczność większego zaangażowania $\mathrm{w}$ te sprawy świeckich wiernych, zwłaszcza w parafiach.

Dopowiedzieć wreszcie należy, że wydarzenia związane $\mathrm{z}$ osobą abpa Bezáka bardzo głęboko dotknęły również zwykłych ludzi. Byli rozczarowani, że takie rzeczy mogą się dziać w Kościele. Jedni obwiniali episkopat o brak tolerancji, inni zastanawiali się, jakie są kryteria wyboru biskupów, skoro już po trzech latach istnieje potrzeba ich odwołania.

Wybór nowego papieża osłabił nieco emocje związane z odwołaniem abpa Bezáka i zwrócił uwagę społeczeństwa na ważniejszy temat. Niekonwencjonalny styl bycia papieża i jego spontaniczne zachowanie przykuły wyraźnie uwagę publicznych mediów, co sprawiło, że pytania dotyczące wydarzeń w archidiecezji trnawskiej zaczynają tracić na znaczeniu.

13 Problem przede wszystkim polegał na tym, że arcybiskup przyjął zaproszenie od świeckich mediów, w których upublicznił zbyt wiele informacji oraz przedstawiał tylko własny punkt widzenia i własne zranienia. Tak o tym myśli większość autorów, jak i również użytkownicy portali społecznościowych: „Tvrdi, že chcel riešit’ nepopulárne veci, ale nepredstupoval pred veriacich a nehovoril: „Sokol je taký a taký“. Ale ked' ho odvolali z pozície, prestalo sa mu to pácit'. Prestali sa mu páčit' pravidlá, ktoré ho vyniesli na vrchol, odrazu pocítil potrebu vyžalovat'sa pred veriacimi. Nespravodlivost'. Stala sa mi nespravodlivost'. Ked' to urobil prvýkrát na omši, dalo sa to pripisat nezvládnutým emóciám, ale teraz, ked' prijíma pozvania do televiznych relácii a očierňuje tam jednotlivých svojich kolegov ale aj celú Cirkev ako takú, ako sa na to treba divat?" http://www.hlavnespravy.sk/monitor-r-bezak-prirovnal-sposob-akym-bol-odvolany-k-estebackympraktikam/57180/ [odczyt: 15.05.2013]. 
Być może nowy papież i jego zaskakujący styl sprawowania urzędu wpłynie również na Kościół słowacki, przyczyniając się do jego większego otwarcia na świat, dialog i aktywniejsze działanie. Papież Franciszek potrafi do tego zainspirować. Aby skutecznie przekazywać wiarę i ją umacniać, potrzebne jest nie tylko jej głoszenie, ale także świadectwo. Stąd oczekuje się, że niektóre problemy zaczną być rozpatrywane $\mathrm{w}$ innej perspektywie, powstaną nowe modele pracy duszpasterskiej i włączy się do niej szerzej świeckich wiernych.

Kościół pragnie się angażować w nowe inicjatywy, podejmować kolejne przedsięwzięcia i posługi. Wymaga to jednak pozyskiwania kolejnych środków finansowych. Prawdą jest, że w Kościele zawsze funkcjonowała zasada pracy na warunkach wolontariatu, ale to wymaga nieustannej opieki kapłana i specjalnego prowadzenia tych ludzi, aby nie stracili zapału i wytrwałości. Niektórych jednak inicjatyw nie da się zrealizować w ten sposób, bo potrzeba na nie sporych nakładów finansowych. Księża na Słowacji są opłacani przez państwo, a Kościół nie ma swoich źródeł finansowania i ich nie organizuje. Nie ma też własnej wizji pozyskiwania samodzielnych środków $\mathrm{i}$ z tego powodu nie próbuje nawet realizować większych projektów pastoralnych. Pozostaje to jedynie w gestii poszczególnych księży, którzy odczuwają potrzebę angażowania się w większe inicjatywy i potrafią skutecznie poszukiwać sponsorów. To dzięki ich talentowi inicjatywy te potrafią osiągnąć większy zasięg, zwłaszcza w tych parafiach, które wykazują sporą efektywność w pracy duszpasterskiej. Ma to również pozytywne skutki dla całego Kościoła. 